\title{
Draženko Tomić*
}

\section{Bioethical topics in the works of Kvirin Vasilj (1917 - 2006)}

\begin{abstract}
SUMMARY
Kvirin Vasilj (1917 - 2006), an authentic thinker of the 20th century, in his philosophical deliberation, he touches on various aspects of human existence, including those that are today identified as bioethical challenges. Thus, bioethics is present in his deliberations, although the term bioethics as such is not found in any of his six hundred works, and they often relate to the meaning, quality, the beginning and the end of human life. Between these two endpoints of an individual's existence, Vasilj places a considerable emphasis on the very practical dimensions of duration, nature protection, quality of life and more. It should also be noted that Vasilj often uses these themes as a basis on which to present or explain some anthropological, even ontological, issues.
\end{abstract}

Keywords: animals, anthropology, bioethics, Kvirin Vasilj, ontology.

\section{Introduction}

Kvirin Vasilj $\left(1917\right.$ - 2006) is a $20^{\text {th }}$-century thinker whose philosophy touches between Kant's cognitive and ethical system on the one hand and the neo-scholastic system on the other. He published most of his books and articles abroad, to also become more present in domestic philosophical circles with several books at the end of the last century. In his works, his intellectual continuity is evident ${ }^{1}$, and in

\footnotetext{
* Correspondence Address: Draženko Tomić, University of Zagreb, Faculty of Teacher Education, Savska 55, 10000, Zagreb. ORCID ID: https://orcid.org/0000-0003-3447-7838. E-mail: drazenko.tomic@ufzg.hr.

1 Tomić, Draženko (2007) Prinos potpunoj bibliografiji Kvirina Vasilja. Hum. Časopis Filozofskog fakulteta sveučilista u Mostaru, 3, 117-151.
} 
the centre of his interest is a man. ${ }^{2}$ Man is, as defined by Kvirin Vasilj ${ }^{3}$ in one of his definitions, a physical and reasonable (i.e. cognitive and intellectual) free and speaking being. It is exactly philosophy that helps man to live in a human way, which should be its definition, the highest and final goal. ${ }^{4}$ Therefore, this philosopher does not seek to establish a certain philosophia perennis. However, he seeks to develop a philosophy of life, that is, philosophia vitae ${ }^{5}$, with the aim of affirming man's original and inimitable (rational) life principle. However, consistent thinking from his own thinking positions that he claims to be based on experience, Vasilj, as a philosopher, was not prevented from perceiving the nature as an inexhaustible source of questions (it is inherent to man to ask questions - animals and God do not ask questions) and, as a theologian, of great secrets. He is convinced that it will remain so forever because man finds (and does not create) life in the world and in himself. ${ }^{6}$

Although Kvirin Vasilj in his articles and books does not mention by name the discipline that studies human action in relation to the living things, and even a man himself, bioethics, the content of this term can be found scattered throughout Vasilj's inscriptions. About ethics itself has been written elsewhere, and the research has begun here on how Vasilj approaches the realisation of life in animals and plants (the second part of the article). However, it appeared that for the understanding of his approach to what was said, it was necessary to expose how Vasilj understands and analyses the human being, as well as the philosophical structures that precede him or those that result from that analysis (the first part of the article).

Bioethical topics that are directly or indirectly touched upon here, such as man's relation to nature and animals, in particular, man's life from conception to death, even economic and political inconsistencies, were for this philosopher like an equation with one unknown. The one and only unknown is the man himself, his origin in particular. Vasilj solves the unknown by introducing into the matter a special intangible life beginning, present in all living things. By the way, let it be mentioned that this philosopher does not use the term ecology in the present sense. However,

2 Juka, Slavica (2007), Filozofski sustav Kvirina Vasilja, Hum. Časopis Filozofskog fakulteta sveučilišta u Mostaru, 3, 9 - 25; Kordić, Ivan (2007). Čovjek u promišljanju Kvirina Vasilja, Hum. Casopis Filozofskog fakulteta sveučilišta u Mostaru, 3, 41-62.

3 Vasilj, Kvirin (1999), Razum i religija, Zagreb: “K. Krešimir”, 19.

4 Vasilj, Kvirin (1966), Temelji spoznaje stvarnosti, Madrid - Valencija: Drina-Press, 10.

5 Tomić, Draženko (2014a), Filozofija Kvirina Vasilja (1917-2006) kao "filozofija života«. Prilozi za istraživanje hrvatske filozofske bastine, 40 (1(79)), 215-231.

6 Vasilj, Kvirin (1984b), Božić, uzvišenje ljudskoga roda na višu razinu postojanja, Hrvatski katolički glasnik, 43 (12), 354-356, 355; Vasilj, Kvirin (1970), Odnos naravnoga reda stvarnosti prema nadnaravnome, Madrid: S. n., 6.

7 Tomić, Draženko (2014), Etika kao filozofija očovječenja u djelu Kvirina Vasilja. Bogoslovska smotra, 84 (1), 97-110. 
in several places $^{8}$ he discusses the ecological factors necessary for the growth and development of plants, animals, and humans.

\section{Life origin as a special essence in a man}

Kvirin Vasilj accepts the results of biology in describing experienced facts, studying the internal structure of living beings, reproduction, ambience and more. He points out that nature rules as if it did not care about individuals but about the preservation of the species, so in this context, he talks about mutations in existing living beings that are within certain limits actually possible, both the positive ones (such as different adjustments) but also the negative ones (such as cancerous changes) and as such, they are often a consequence of external influences. He says it is not possible to know where the historical boundaries are of changing and developing of one living being into the other, but also that in nature, there are some maximums beyond which it does not exceed, so living beings can evolve to a certain degree that the species can no longer surpass. Hence, he writes about "the fourth dimension of living beings", i.e. the internal time of species development. When he looks at the man in this context, he feels that the man is at the top of developing his physical capabilities. ${ }^{9}$

On the other hand, when Kvirin Vasilj discusses living beings as a philosopher, which is much more often than his above observations, he then claims that human beings have two constitutive but different origins of the essence: one that represents an already completed essence and the other essence in becoming, i.e. the one that is created by the assimilation of the matter. In support to the claim, he states the apparent multiplicity of action of living beings by which physical and chemical elements connect into a single whole, so that the living organism causes (produces) itself in its own physical component. As it is logically impossible for the whole in the same living being to produce parts and the parts to produce the whole, that is, that something is its own cause and effect, Vasilj concludes that there is a special life origin in the living organism. That origin is a new and original essence in relation to the matter, which according to the author, escapes the knowledge of physics precisely because it is inherently different from other physical cause, but not necessarily unrealistic simply because man has no direct mental maturity about it. The compatibility of this life origin and the material component is that it enables new chemical syntheses in the material component. It elevates it to a higher level of existence and action. In contrast, the material component, in addition to carrying it

8 Vasilj, K. (1966), 10, 80; Vasilj, Kvirin (1996), Isus iz Nazareta, Zagreb: “K. Krešimir”; Vasilj, Kvirin (1998), Čovjek, njegova veličina i njegova bijeda, Mostar: ZIRAL, 2.

9 Vasilj, Kvirin (1975a), Duh zajedništva, Hrvatski katolički glasnik, 34 (11), 328-329; Vasilj, Kvirin (1978), Filozofjja očovječenja i počovječenja, Duvno: Naša ognjišta, 30, 64; Vasilj, K. (1966), 284-287. 
in itself, the ability to connect with the life origin into a living being, it also enables it to interact actively with other beings. ${ }^{10}$ Certainly, the question of how and why the life origin is differently realised in the order of plants, animals and humans, but also in these orders in uncountable varieties, should be addressed. Vasilj might also be aware that this question should be answered:

"The life force, as an inexhaustible artist, gives shape to all living beings, colour to all flowers, design to all leaves. Life is a divine chemist that gives taste to fruits and spices, fragrance to flowers. It changes water and carbonic acid into sugar and wood, thus releasing oxygen, needed for animals to breathe. The life force is an excellent mathematician who, with the help of the minimum of materials achieves the maximum." 11

The author's second proof of the existence of a special intangible origin in living beings comes from his statement that it is in principle not possible to produce living beings from inanimate matter in scientific laboratories. It would be easier to produce animals from ants, this author claims, than to produce a living cell from dead matter, or to produce gold from other materials than to produce life without the "germ of life" in inanimate matter. Living beings, therefore, have more essence in them than the sum of elements of which they are built, Vasilj deliberates further. Therefore, he cannot justify in any way the claim that life comes from inanimate matter by some (accidental) synthesis. ${ }^{12}$

From the listed points of view, Vasilj also analyses a man and warns that his complexity, like the complexity of other living organisms, is not only reflected in the macromolecular structure, but also in the special way in which molecules are hierarchically integrated into individual organs and finally in a whole. A certain life origin is responsible for that. At the level of this life origin, according to our philosopher, the destiny of a man is decided, not at the level of the structure of his genes. In the book The Philosophy of Humanization and Dehumanization, he refers to Dawkins's book The Selfish Gene:

"According to Dawkins, there are no living molecules because of man, but man exists because of living molecules, which have no awareness of their own reality. That would be the highest purpose of man's existence and the greatest reason for his being. That would be man's worldview and outlook. If a lot of absurdities were to follow from this negative biology about a man's life and his actions, maybe Dawkins did not even think about it: he does not have to pay attention to philosophical theories

10 Vasilj, K. (1966), 276-281; Vasilj, K. (1978), 29-38, 44.

11 Vasilj, K. (1966), 331.

12 Vasilj, K. (1966), 278; Vasilj, K. (1978), 33; Vasilj, Kvirin (1997), Religija. Prirodne i drustvene znanosti, Mostar: ZIRAL, 103. 
when he knows it all by virtue of his facts. It is then that Nietzche is right, that only great people have the right to life, as in them these molecules came to their highest expression and to their highest perfection." ${ }^{3}$

Furthermore, from the postulate on the exclusive life origin in the matter, Vasilj deduces that the appearance of a man does not necessarily presuppose the existence of some transitional form, hominid animals. Moreover, in principle, it is not possible to interpret the origin and development of human life from some transitional form due to 1) human origin constituting essence in itself and not a real change of the existing essence, 2) human origin in its essence cannot originate from actions of natural causes and 3) human origin as the origin of man necessarily participates in the formation of his own physical components. Well, by bringing his thought to the extreme limits, Vasilj may claim that no living being, who is not already human, can develop a body that could be equally the same to the human body - from the beginning, it has to be shaped from the man himself and in the manner of man in order to have a human life origin. Thus, Vasilj rejects theories about the development of men from hominid animals. ${ }^{14}$

Vasilj refers to, as he calls it, »biological philosophy«. It offers answers to the question of what life is, and how it came to be, what the difference between living and nonliving beings is. Their thinking and real mistake are that they claim that what is not happening now, surely happened in the time of which man has no immediate knowledge. Thus, according to this author, the premise of the general evolution of life from some simple, primal cell is not some established scientific fact, but a hypothesis about the appearance of life on Earth in general which does not represent a set of proven facts but a set of assumptions which are valid just as much as the principles underlying them. ${ }^{15}$ And continues:

"Furthermore, these very same people, who do not recognise the causal relations between natural beings, as we have no direct intellectual intuitions about them, find such causal relations between historical beings only on the basis of temporal relations, although the analogy of experience and first principles of cognition with real value preclude us from also interpreting those temporal relations as causal relations." ${ }^{16}$

13 Vasilj, K. (1978), 57.

14 Vasilj, K. (1978), 44-45; Vasilj, K. (1966), 697-698; Vasilj, Kvirin (1990), Kruh naš svagdašnji. Chicago: ZIRAL, 19; Vasilj, Kvirin (1968), Zašto vjerujem? Madrid: S. n., 256.

15 Vasilj, Kvirin (1987), Vječni život, Chicago: ZIRAL, 13; Vasilj, K. (1978), 27; Vasilj, Kvirin (1994), Filozofija života, Zagreb: “K. Krešimir”, 36; Vasilj, K. (1996), 183; Vasilj, K. (1966), 284-287; Vasilj, K. (1997), 102; Vasilj, K. (1968), 256.

16 Vasilj, K. (1966), 282. 
Further to the claims on man as the unity of life and material origin, Vasilj wonders when this union of higher and lower origin occurs and answers that this union should be placed to the very beginning. Namely, only from a human fertilised cell, a human being can develop, and to Vasilj this is a signal that in it, from the very beginning, there is some origin which seems different, e.g. from a fertilised cell of a monkey. Therefore, Vasilj rejects the view the life origin of a human would merge at some point with some developed human organism in which all preparations for such act were completed. Life origin of a human, from the very beginning, is involved in the production of its own body. Therefore, a fertilised cell contains in itself the origin of biological life in the manner of a whole, so it should be observed and respected as a complete human being, and the principle that it is not allowed to directly kill an innocent man should be applied to it. Vasilj expresses disagreement with abortion in several of his works, despite the immediate benefit of the procedure itself. The aforementioned thesis that he began to discuss, brings Vasilj to the insistence on responsible parenthood. It consists of the fact that partners should not give birth to as many children as they can conceive, as children need to be raised, educated, directed in life. The author does not dispute the artificial control of marital acts when partners have a reason for that as, he continues, if the marital act is to be open to the transfer of life, it should not always be open to conception. ${ }^{17}$ It should also be noted that Vasilj criticised the encyclical Humane vitae on several occasions at the time when it was published. ${ }^{18}$

Vasilj, without any exception, insists on the need to respect the ,innocent human life which is in harmony with other people" at a very stage of its development. If this principle is denied, the absolute value, human life is exposed to destruction. In the modern civilisation, to his great regret, Vasilj recognises only the principle of selfishness, which is strong enough that every moral evil is transformed into physical gain or at least is presented weak and without lasting consequences, an attitude that quickly „animalises“ the man who is otherwise in danger of becoming the worst animal of all animals. He concludes, with regret, that human society has so far not found a way to defend human life effectively. ${ }^{19}$

17 Vasilj, K. (1978), 9-124.

18 Tomić, Draženko (2015), Filozofija i religija Kvirina Vasilja. U: Vasilj, Kvirin Religija i nereligija. Rasprave i članci (pp. 7-66), Zagreb: Glas Koncila.

19 Vasilj, K. (1978), 72-76. 


\section{Life origin as a special essence in plants and animals}

Kvirin Vasilj admires the phenomena in nature: the organisation of inanimate matter, the diversity of plants and animals. It is from botany and zoology (e.g. spawning of eels, migration of birds and similar). Vasilj gives numerous examples to illustrate some of the most complicated philosophical settings. All of these many different connections and factors put a man into a state of annoyance and confusion. ${ }^{20}$ That is why Vasilj says this:

"Namely, however deeply our mind penetrates the secrets of reality, however seriously he becomes aware of the existence of physical agents and their laws of action, he will never have immediate intuitions about the metaphysical finality in the world, but will always remain subject to the riddle of admiration and wonder, that nature achieves by mechanical action -from the point of physical finality it signifies the sequence of a mere chance - the same results, which would, according to the understanding of [meta]physical finality, could be only achieved by the harmonious participation of an extraordinarily intelligent and powerful being with their agents in the physical order." $^{21}$

Advocating human rights in which the life origin is realised, Vasilj is aware of environmental issues and also advocates plants and animals whose very existence is called into questions by the very man's insatiable greed. He resolutely condemns any torture of animals, although, for the sole purpose of a higher good, he agrees in principle with experiments on animals, as he elaborates further, what disorder and suffering are from the view of the animal also has some order and meaning from the point of a man. ${ }^{22} \mathrm{He}$ also casually presents some of his own assumptions about the value of animals, which was why they were sacrificed to deities in primitive cultures. ${ }^{23}$

Noticing how man also applies on himself experiences acquired in interactions with flora and fauna to find out something about his own origin and his cognition, Vasilj suggests that man relies on his own rational experience about himself as man deduces the life and habits of animals and plants, from his own perspective and analogy pursuant to the habits of his own species. ${ }^{24}$

"It is both pleasant and fun to fish, to socialise with animals and plants in nature, to climb mountains as a vacation. But to turn it into a purely human vocation

\footnotetext{
20 Vasilj, K. (1966), 331-333.

21 Vasilj, K. (1966), 334.

22 Vasilj, K. (1968), 57, 129

23 Vasilj, Kvirin (1983), Misli o religiji, Chicago: Hrvatska franjevačka tiskara, 86.

24 Vasilj, Kvirin (1984a), Filozofija ljudskog duha. Teorija spoznaje. Kritika filozofje o Bogu, Chicago: ZIRAL, 188; Vasilj, K. (1978), 28; Vasilj, K. (1990), 118.
} 
would mean to make life boring and painful and deprive it of the greatest spiritual assumptions and pleasures, that the development of his own spirit prepares for and gives him. Digging through earth and space allows man his physical life. But measuring in the depths of a human being, in accordance with logical and ethical laws, enables a man to live his spiritual life. Even the deepest and most fertile furrows are not in the earth but in the human spirit." ${ }^{25}$

Our author reminds man that he is one with nature: he is, like any other thing, subject to the law of gravity; as an animal he feeds on the fruits of the earth, grows and multiplies; like the animal itself and has the sense of comfort, observes the same objects. That sensory origin of which a man shares with all nature, in man it further demonstrates an extraordinary creative power: animals are not able to prepare food artificially, to protect themselves from natural disasters artificially or to be treated in this way; animals may, however, endure hunger or thirst, but for the most part, they cannot consciously give up food or water; they permanently live in the same way, while man is able to act not only in a new but also an unexpected and opposite way; an animal expresses its inner mood through movements, sounds and similar, while man has a developed, articulate language, through which he can communicate his thoughts; animals do not have any religion, they are not able to philosophise, to experience something in the form of being, and therefore cannot consciously rise above physical things; although noticing objects, they probably have no experience of beautifying; ultimately, the man remembers all the dead. ${ }^{26}$

Here listed differences between man and animals are important and far-fetched differences that are not reflected only in a particular organisation of the matter they absorb, in the sensory apparatus itself, but rather in the specific principle involved in each act of cognition - reason. (Wanting to point out this difference, Vasilj uses expressions depending on the context and complexity of the text: mental maturity, intellectual intuition, the special principle of life, spiritual origin, human spirit, and sometimes a person. Understandably, he is also aware that these are not synonyms for the term reason, although it is obvious that he uses it in that sense. The term reason is predominantly used here, even when it is obviously a matter of cognition as the marks of reason are not questioned as much as the very fact of its existence and exclusivity.) It is precisely the reason that is a great treasure that makes man unique in the universe. The reason is the concentration of essence different from all matter,

25 Vasilj, Kvirin (1984), Politika. Politička teorija obzirom na osobnu i društvenu odgovornost, Chicago: ZIRAL, 150 .

26 Vasilj, K. (1966), 524; Vasilj, K. (1968), 28, 86, 136; Vasilj, Kvirin (1972), Sloboda i odgovornost. Cudoredni zakon, Rim: Izdanja Ranjeni labud, 93, 118, 200, 300; Vasilj, K. (1996), 99-100; Vasilj, Kvirin (1976), Marksizam $i$ kršćanstvo. Razgovor s drom Brankom Bošnjakom, piscem knjige "Filozofija i kršćanstvo", München - Barcelona: Knjižnica Hrvatske revije, 120; Vasilj, Kvirin (1979), Ljepota i umjetnost, Chicago: ZIRAL, 47, 116, 140; Vasilj, K. (1978), 39; Vasilj, K. (1998), 111; Vasilj, K. (1990), 31. 
constitutive origin in the very concept of man. Thanks to reason, when a man and an animal look at the same thing and produce some sensory image in their imagination, man, in the very act of seeing, in principle sees more than an animal, as in addition to the sensory image, he also forms the notion of that thing, intuits the reality of being. Therefore, Vasilj states the principle that every act of a man's sensory observation is connected with the mental maturity into an indivisible whole. Therefore, the principal distinction between man and animal is manifested immediately in the first beginnings of his cognition. It is this huge distinction, a huge leap that goes beyond all space capabilities and dimensions. Whoever claims otherwise should be consistent, so if man's cognition is initially equated with the one of animal, that is, with sensory observation, then it must remain at the level of animal capabilities at its end, and this is what nobody wishes nor can accept for themselves. ${ }^{27}$ Among other examples illustrating this, we highlight this sentence: "Monkeys, because of their greater resemblance to man, are a living mirror, in which a human person can see its insignificance and minuteness as an animal being." ${ }^{28}$

Animals cannot think as they are unable to form concepts and ideas, Vasilj claims contrary to those who are convinced that at least higher animal species are capable of thinking. If an animal were able to think, then it would probably be able to know through reasoning, and therefore to raise its culture and civilisation. Moreover, animals show no such progress in their way of existence. Animals are neither selfish nor selfless because they have no reason to limit their selflessness or multiply their selfishness, they do not care about others when they are hungry and thirsty, they do not show any special respect for anyone's life, but they live for themselves and others only insofar as the life of the other living being is inextricably linked to their life (pack, cubs). Animals cannot experience the magnificence of great things as they have no sense of comparison. With this, the vocalisation of some animals cannot be called a conversation with a greater or smaller number of established signs that animals express their condition. Furthermore, the fact that animals are able to imitate one another, including a man, is not proof of their ability to think, but merely an expression of events at the level of sensory action. ${ }^{29}$ Therefore: "A man may think that he is equal to animals only because he is fundamentally different from animals." ${ }^{" 30} \mathrm{In}$ the same sense, he continues elsewhere:

27 Vasilj, K. (1984a), 15; Vasilj, K. (1983), 67, 139; Vasilj, K. (1987), 12; Vasilj, K. (1979), 146, 168, 171; Vasilj, K. (1996), 33-34, 125; Vasilj, K. (1966), 103; Vasilj, K. (1999), 20; Vasilj, Kvirin (1975), Umjetnost i ćudorednost, Hrvatski kalendar, 32 (32), 54-61, 54; 1981, 87.

28 Vasilj, Kvirin (1978a), O nadvladavanju ograničenosti, Hrvatski katolički glasnik, 37 (9), 285-286, 285.

29 Vasilj, K. (1978), 39, 80; Vasilj, K. (1968), 57; Vasilj, K. (1979), 21; Vasilj, Kvirin (1990a), Praktični materijalizam, Hrvatski katolicki glasnik, 49 (9), 263, 263; Vasilj, Kvirin (1987a), Posjedujemo samo jedan jedini život: dakle, živimo ga, Hrvatski katolički glasnik, 46 (10), 292-293, 292.

30 Vasilj, K. (1990), 234. 
"The animal is not a threatened and restricted man from the outside. Therefore, it is completely inappropriate and unrealistic effort of some biologists to interpret the formation of concepts and ideas to the way of reproduction of human beings through sexual or asexual conception, because we form our concepts based on the mental maturity - every man for himself - while the reproduction of human beings at their biological level takes place completely unconsciously: we do not understand the laws of cognition by means of biological laws, but seek to understand biological laws in accordance with some logical and cognitive laws of human thought and maturation. A human person with inherited genes does not inherit the knowledge of his parents, but rather needs to acquire it from the beginning, to deepen and expand it." 31

Vasilj notes with regret every time that many people reduce their knowledge more and more to just what their sensory eyes see and notice. Tragically, they reduce themselves to the level of lower living beings who only have sensory powers. "However, the more a human mind progresses in its knowledge of natural beings, the less it held to its own being and therefore to the intrinsic value of a human person. In his thoughts, he reduced the human person more and more to the level of unreasonable animals and was almost proud of that and finally interpreted his origin from a simple matter." ${ }^{2}$

The reason for degradation of the human being is pleasure, as man, thanks to his mind, is able to develop and perfect his animal element far more than the animal itself: for example, enjoying food, reproduction, and similar. On the other hand, a man, with his unreasonable use of the environment, has created an unhealthy environment for the existence of plants, animals and himself. In enormous greed for getting rich, he did not know or did not want to establish a balance between his serving to nature and respecting the nature as a whole of natural beings, who, ultimately, enable the realisation of his own being, Vasilj finds. Moreover, greed is the result of the condition in which man, his spiritual pursuit for infinity, moved to the sensory need for space. Hence, he cannot, like an animal, be content with the most necessary part of the earth, but to strive to possess the whole land, and here, at least according to Vasilj, he cannot satisfy nor fulfil the meaning of his existence. ${ }^{33}$

Our author recounts an event from a zoo where they advertised that the most bloodthirsty animal could be seen in a special cage behind bars. When visitors would walk in, they would see their own reflection in the mirror behind bars. Vasilj also wonders if a man is the most bloodthirsty animal. His answer is affirmative for all the cases when man ceases to live as a spiritual being in the broadest sense of the word:

31 Vasilj, K. (1978), 39-40.

32 Vasilj, Kvirin (1988), Ljudski razum protiv sama sebe, Hrvatski katolički glasnik, 47 (1), 2-3, p. 3.

33 Vasilj, K. (1984), 159-160; Vasilj, K. (1984a), 403; 1986, 195. 
he opens wide the door to the slavery of man to man, things and himself, turning into the most bloodthirsty animal. He finds vivid examples in the history of the 20th century when, in the name of national and ideological selfishness, more than a hundred million innocent people were killed, by the very people who believed that a man has developed from animals and dies like all animals. ${ }^{34}$ It is a "physical man" who, according to the principles of utilitarianism, finds no reason for the existence of old and sick people. ${ }^{35}$

"Hence the ever-diminishing price of human life; we are already reading suits in worldwide newspapers, that some individuals are forced to spend money to support old people, who no longer contribute to the human society: these people do not see the meaning of love for their fellow human nor its value, so they think, if money is invested for the elderly, terminally ill, mentally and physically impaired, to invest their property into nothing. These people do not realise that precisely the attitude towards the most powerful, most neglected persons of the human society is the proof of the culture or non-culture of a man and his community. But it is not possible to see the exaltation of love and sacrifice within pure physical knowledge." ${ }^{36}$

\section{Conclusion}

This presentation has shown that Kvirin Vasilj, a kind of a $20^{\text {th }}$-century thinker, will not and cannot deny the results of contemporary research in the field of biology and related sciences. It has been shown that in many of his works, he focuses his attention on living beings, plants, and animals, both generally and individually. $\mathrm{He}$ is aware that a man cannot escape the influence of nature, that a man by his physical component is completely dependent on nature - without nature, there is no man. Moreover, this philosopher is ready to claim that a man, as we know him, is at the height of his development.

However, as much as he is willing to say that nature and man are subject to change, he is willing to state that there are some ,immovable“ elements which, - although active in the constitution and action of the living beings - are not „moved“ by nature itself, and therefore not of material origin, and therefore unavailable to natural and scientific research methods.

34 Vasilj, K. (1999), 19, 30; Vasilj, K. (1987), 79; Vasilj, K. (1984), 157; Vasilj, Kvirin (1956), Veličina i bijeda čovjeka - skraćeni svijet M. Krleže, Danica, 36 (51-52, 19. XII. 1956), 6-7, 6; Tomić, Draženko (2018), Kritika nekih postavki filozofije marksizma u Kvirina Vasilja. Prilozi za istraživanje hrvatske filozofske baštine, 44 (1 (87)), 187-202.

35 Vasilj, K. (1978), 80; Vasilj, K. (1987a), 292.

36 Vasilj, K. (1978), 86. 
No matter how much Vasilj mentioned and respected living beings for the very fact that they are „alive“, he, it seems, does that by emphasising the distinction between a man and an animal, to protect the exclusivity of a special origin within the man himself - the reason, that condensation of the essence of the different from other matter, constitutive origin in the very concept of a man. Thus perceived, bioethical topics of Kvirin Vasilj are in their essence anthropological topics. Moreover, the author of this article is free to state, what is today called bioethics, can be reduced to ontology in Vasilj's system of thought without many leftovers. Thus, bioethical themes become the backdrop under which, who knows how many times, there is the reprise of the ontological question about the world and the man. ${ }^{37}$

Vasilj's consistency in insisting on the exclusive principle of life in man forced him to deny the existence of transient forms, hominid animals (because the life origin is a constituent component in the making of a physical component), and to also express their disagreement with the hypothesis of the emergence of living and inanimate matter, justifying that it cannot be concluded from causal relationships on the basis of temporal relations. From the aforementioned constitutionality of a life origin from the very conception (as it is already present recording by which a man will be formed and who will synthesise a substance in their own special way) Vasilj advocates the effective protection of human life from conception to natural death.

The fact that the true reality (especially the life origin), which Vasilj sees through the power of reason in nature is not reachable by senses, causes in this philosopher a fear for people not to reduce their knowledge only to that directly recognisable and thus tragically reduce themselves to the level of everyday living beings who only have sensory powers. If, however, a man moves his evident spiritual pursuit of infinity to material, to space, there is greed thriving in him, which makes the environment unhealthy for the existence of plants, animals, and the man himself (environmental issues), excruciating situations of wars and disagreements between people and nations. ${ }^{38}$ Hence, Vasilj reminds that the excavations of the latitudes of the earth and universe should not be a substitute for the excavation of depths of the human being in accordance with logical and ethical laws. ${ }^{39}$

In conclusion, it may be said what has already been said: some systems of thinking, lack of human knowledge on the physical processes in organisms by the introduction of intangible origins of existence, and consequently, dogmatise human ignorance of the same processes. On these petrified foundations, very solid structures are being

37 Tomić, Draženko (2013), Preispitivanje dokaza Božjeg postojanja u filozofiji Kvirina Vasilja. Obnovljeni život: časopis za religioznu kulturu, 68 (4), 457-472.

38 Tomić, D. (2015).

39 Vasilj, K. (1984), 150. 
built not only of religion but also of philosophy. One who moves into them really has the impression of being protected from the meaninglessness of existence, even from the relentless disintegration of the physical component of one's own being. However, if such a sequence of thought is rejected in its newly painted foundations, its results need not necessarily be rejected: in the man himself, it would be useful to have a somewhat different origin than the rest of the living/animal world and to direct the view to that firm point in nature and the universe - to himself, the man who is conscious of himself and others. With such, at least part displacement of man's existence from nature to non-nature, unlocked are unprecedented possibilities of development of his spirit. Experience shows that this is not necessarily bad for the man, but if it not necessarily bad, then it is not necessarily untrue. Man trapped in nature emerges and disappears together with it, confirms the thought of Kvirin Vasilj, and from the consciousness of the dependency on nature, man necessarily tends to conquer it, and in this relentless struggle can become an animal worse than all other animals.

\section{References}

Juka, Slavica (2007), Filozofski sustav Kvirina Vasilja, Hum. Časopis Filozofskog fakulteta Sveučilišta u Mostaru, 3, 9- 25.

Kordić, Ivan (2007), Čovjek u promišljanju Kvirina Vasilja, Hum. Časopis Filozofskog fakulteta Sveučilišta u Mostaru, 3, 41 - 62.

Tomić, Draženko (2015), Filozofija i religija Kvirina Vasilja, u: Vasilj, Kvirin, Religija i nereligija.Rasprave i članci, Zagreb: Glas Koncila, 7-66.

Tomić, Draženko (2018), Kritika nekih postavki filozofije marksizma u Kvirina Vasilja. Prilozi za istraživanje hrvatske filozofske baštine, 44, 1 (87), 187-202.

Tomić, Draženko (2014), Etika kao filozofija očovječenja u djelu Kvirina Vasilja. Bogoslovska smotra, 84, $97-110$.

Tomić, Draženko (2014), Filozofija Kvirina Vasilja (1917-2006) kao "filozofija života«. Prilozi za istraživanje hrvatske filozofske baštine, 40, 1(79), 215 - 231.

Tomić, Draženko (2013), Preispitivanje dokaza Božjeg postojanja u filozofiji Kvirina Vasilja. Obnovljeni život: časopis za religioznu kulturu, 68, 4, 457-472.

Tomić, Draženko (2007), Prinos potpunoj bibliografiji Kvirina Vasilja. Hum. Časopis Filozofskog fakulteta Sveučilišta u Mostaru, 3, 117-151.

Vasilj, Kvirin (1976), Marksizam i kršćanstvo. Razgovor s drom Brankom Bošnjakom, piscem knjige "Filozofija i krš́áanstvo", München - Barcelona: Knjižnica Hrvatske revije.

Vasilj, Kvirin (1984), Božić, uzvišenje ljudskoga roda na višu razinu postojanja, Hrvatski katolički glasnik, 43, 12, 354-356, 355.

Vasilj, Kvirin (1998), Čovjek, njegova veličina i njegova bijeda, Mostar: ZIRAL.

Vasilj, Kvirin (1975), Duh zajedništva, Hrvatski katolički glasnik, 34, 11, 328-329.

Vasilj, Kvirin (1984), Filozofija ljudskog duha. Teorija spoznaje. Kritika filozofije o Bogu, Chicago: ZIRAL.

Vasilj, Kvirin (1978), Filozofija očovječenja i počovječenja, Duvno: Naša ognjišta.

Vasilj, Kvirin (1994), Filozofija života, Zagreb: “K. Krešimir”. 
Vasilj, Kvirin (1996), Isus iz Nazareta, Zagreb: "K. Krešimir”.

Vasilj, Kvirin (1990). Kruh naš svagdašnji, Chicago: ZIRAL

Vasilj, Kvirin (1979), Ljepota i umjetnost, Chicago: ZIRAL

Vasilj, Kvirin (1988), Ljudski razum protiv sama sebe, Hrvatski katolički glasnik, 47, 1, 2-3.

Vasilj, Kvirin (1983), Misli o religiji, Chicago: Hrvatska franjevačka tiskara.

Vasilj, Kvirin (1978), O nadvladavanju ograničenosti, Hrvatski katolički glasnik, 37, 9, 285-286.

Vasilj, Kvirin (1970), Odnos naravnoga reda stvarnosti prema nadnaravnome, Madrid: S. n..

Vasilj, Kvirin (1984), Politika. Politička teorija obzirom na osobnu i društvenu odgovornost, Chicago: ZIRAL.

Vasilj, Kvirin (1987), Posjedujemo samo jedan jedini život: dakle, živimo ga, Hrvatski katolički glasnik, 46, 10, 292-293.

Vasilj, Kvirin (1990), Praktični materijalizam, Hrvatski katolički glasnik, 49, 9, 263.

Vasilj, Kvirin (1999), Razum i religija, Zagreb: "K. Krešimir”.

Vasilj, Kvirin (1997), Religija. Prirodne i drustvene znanosti, Mostar: ZIRAL

Vasilj, Kvirin (1972), Sloboda i odgovornost.Ćudoredni zakon, Rim: Izdanja Ranjeni labud.

Vasilj, Kvirin (1966), Temelji spoznaje stvarnosti, Madrid - Valencija: Drina-Press

Vasilj, Kvirin (1975), Umjetnost i ćudorednost, Hrvatski kalendar, 32, 32, 54-61.

Vasilj, Kvirin (1956), Veličina i bijeda čovjeka - skraćeni svijet M. Krleže, Danica, 36, 51-52, 19. XII. 1956.), 6-7.

Vasilj, Kvirin (1987), Vječni život, Chicago: ZIRAL.

Vasilj, Kvirin (1968), Zašto vjerujem? Madrid: S. n.

\section{Bioetičke teme u Kvirina Vasilja (1917. - 2006.)}

\section{SAŽETAK}

Kvirin Vasilj (1917. - 2006.), autentični mislilac 20. st., u filozofskim promišljanjima dotiče se različitih aspekata ljudskog postojanja, pa i onih koji se danas identificiraju kao bioetički izazovi. Tako je bioetika prisutna u njegovim promišljanjima, mada pojam bioetika kao takav ne nalazimo niti u jednom od njegovih šestotinjak djela, a tiču se najčešće smisla, kvalitete, početka i svršetka ljudskoga života. Između tih dviju krajnjih točaka pojedinčeva postojanja Vasilj značajan naglasak stavlja upravo na praktične dimenzije trajanja, zaštitu prirode, kvalitetu življenja i drugo. Valja istaknuti i to da Vasilj ove teme nerijetko koristi kao podlogu na kojoj će iznijeti ili kojom će obrazložiti neka antropološka, pa i ontološka, pitanja.

Ključne riječi: antropologija, bioetika, čovjek, ontologija, Kvirin Vasilj, životinje. 